\title{
МЕРКУР БОЦЕ У НАРОДНОМ МУЗЕЈУ У ПОЖАРЕВЦУ
}

\author{
Антонија С. Ропкић Ђорђевић \\ Београд \\ e-mail: antonijaropkic@yahoo.com | Кратко саопштење \\ Примљено: 1. 5. 2020. УДК: 904:738”01/02”(497.11) \\ Прихваћено: 31. 7.2020. 069.51:903.23”01/02”(497.11)
}

\begin{abstract}
Апстракт: У збиричи Народног музеја у Пожаревиу налазе се разноврсни облици стаклених посуда које потичу са некропола римског Виминаиијума. У тексу је обрађено пет посуда четвртастог реципијента, које су због специфичне форме опредељене као Меркур боче. Нађене су приликом заштитних археолошких ископаваьа некропола Пећине и Више гробаља. ${ }^{1}$ На основу покретног материјала и новца датоване су у период од прве половине II до друге половине III века и највероватније представљају импорт из италских и галско-германских радионица.
\end{abstract}

Кључне речи: Народни музеј Пожаревац, Виминаџијум, некропола Више гробаља, некропола Пећине, стаклене посуде, Меркур боче, II-III век

Током деценијских заштитних археолошких истраживања римског Виминацијума, у гробовима и на жртвеним површинама, нађено је преко 2000 стаклених посуда (Спасић-Ђурић, Д. 2002, 108). У богатој колекцији предмета од стакла посебну пажњу заслужују посуде које не представљају тако честе налазе на територији данашње Србије. Ради се о пет Меркур боца (тип Isings 84). Са некрополе Пећине потиче једна боца (Кат. 1, Т. 1), а четири боце су констатоване приликом истраживања некрополе Више гробаља (Кат. 2, Т. 2; Кат. 3, Т. 3; Кат. 4, Т. 4; Кат. 5, Т.5).

Меркур боце карактерише четвртасти реципијент, чија висина варира од 14 до 21 цм, и цилиндрични, издужени врат. Рађене су од дебљег стакла, техником дувања у калуп, са слободно формираним вратом и ободом. Боца нађена у гробу Г1-625 на некрополи Више гробаља (Кат. 3, Т. 3) рађена је од дебљег стакла, које ка дну, са унутрашње стране реципијента, постаје још дебље, што смањује запремину боце. Визуелна варка којој су прибега-

\footnotetext{
1 Заштитна археолошка ископавања на античким некрополама Пећине и Више гробаља спровели су Републички завод за заштиту споменика културе, Археолошки Институт САНУ и Народни музеј у Пожаревцу. Стаклене посуде се налазе у депоу Народног музеја у Пожаревцу, а пратећа теренска и техничка документација коришћена у овом раду налази се у Одељењу за истраживање, заштиту и документацију Републичког завода за заштиту споменика културе у Београду.
}

Гласник Српског археолошког друштва

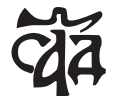

Journal of Serbian Archaeological Society 
вали антички трговци како би купце уверили да се у посуди налази више течности него што заправо посуда садржи (Morin-Jean 1913, 68 Fig. 61, 62). Две боце су рађене од зеленкастог, слабо прозирног стакла, док су три боце рађене од слабо прозирног стакла млечнобеле боје. Код два примерка на благо удубљеном дну налазе се рељефни печати у виду кружића распоређених на угловима и у средини (Кат. 2, Т. 2) и рељефни печат у облику розете са четири латице (Кат. 3, Т. 3). Обе боце су нађене на некрополи Више гробаља.

Боце су похрањене у гробовима спаљених покојника етажног типа, с богатим гробним прилозима. У гробу Г1-1122 са некрополе Пећине, осим Меркур боце (Кат. 1, Т. 1), нађени су фрагментовани црвено печен и црвено бојен жижак и бронзани новац. ${ }^{2}$ У гробу Г1-129, поред Меркур боце (Кат. 2 , Т. 2), нађени су и бронзани новац, наруквица од гвоздене жице кружног пресека, бронзана алка, пређица од бронзе са трном кружног облика. ${ }^{3}$ У гробу Г1-625, који је девастиран укопима млађих гробова, уз две Меркур боце (Кат. 3, Т. 3; Кат. 4, Т. 4) нађени су фрагменти стаклене посуде без елемената за реконструкцију и фрагменти црвено печене и бојене амфориске. ${ }^{4} \mathrm{У}$ гробу Г1-719 нађени су бројни предмети: бронзани новац; два лонца рађена од каолинске глине ребрасто профилисаних трбуха са једном тракастом дршком; фрагменти црвено печеног и бојеног крчага са две тракасте дршке; фрагментована бронзана игла са главом у виду шишарке; мања бронзана спатула са кружном главом; две фрагментоване украсне коштане игле са равно зарезаним главама; фрагментована коштана игла за шивење; минђуше типа каричице од златне жице са привеском од златног калотастог лима. ${ }^{5}$ На основу гробних прилога, боце су датоване у период од прве половине II до средине III века.

Меркур боце карактерише дуг цилиндричан врат са прстенасто задебљаним ободом и уским отвором, који су омогућавали постепено и одмерено изливање течности. На основу форме сврстане су у тоалетне боце у којима су могли бити чувани козметички или медицински препарати (Fadić, I. 2011, 336; Taborelli, L. 1983, 45, са нап. 63). Morin-Jean помиње боцу нађену у Клермару, у близини Ремса, са натписом који је прочитан

\footnotetext{
${ }^{2}$ Гроб је, на основу новца кованог у време цара Хадријана $(117-138)$, датован у период II века (Vojvoda, M., Mrđić, N. 2017, 155, kat. 638).

${ }^{3}$ Г1-129 није публикован. Подаци о гробу и гробним прилозима преузети су из теренске документације.

${ }^{4}$ Г1-625 није публикован. Подаци о гробу и гробним прилозима преузети су из теренске документације.

${ }^{5}$ Гроб је, на основу новца кованог у време цара Хадријана (117-138), у периоду од 125. до 134. г., датован у период II века (Vojvoda, M., Mrđić, N. 2015, 130, kat. 697).
} 
као Firmi Hilari ad tylosim aromaticum. Читање и препознавање речи Tylosis, која означава обољење очних капака, навели су на смелију претпоставку да су се у боци налазиле капи за очи (Arveiller, V. 2006, 125; Morin-Jean. 1913, 68-70, са нап. 3).

Меркур боце своје име дугују примерцима који су на бази имали рељефне представе бога Меркура. Римски бог Меркур, гласник богова и бог трговине, трговаца и изобиља, приказиван је у више варијанти и његови атрибути су се мењали. Представе бога са препознатљивим атрибутима: путничким шеширом (petasos), крилатим сандалама (pedila), петлом, овном или корњачом, врећом новца (marsupium) или кадуцејем (caduceus) у рукама, налазе се на примерцима из Пуле и Задра (Eterović, A., Štefanac, B. 2013, 133-137; Fadić, I. 2005, 205-213). На појединим примерцима, на базама се налазе представе богиње среће Фортуне са рогом изобиља (Cornucopia) или велом, и Генија на олтару, такође са рогом изобиља. Приказане су и различите животиње, амфоре и куће. Јављају се и флорални и геометријски мотиви: палме, гроздови, бршљан, розете, кругови на угловима база или концентрични кругови. Рељефне представе су често биле уоквирене и ознакама које су интерпретиране као ознаке мајстора или радионица, или су означавале медицинске или козметичке препарате који су се налазили у боцама, или произвођаче препарата (Arveiller, V. 2006, 125; Foy, D. 2015. 382; von Saldern, A. 2004, 311-312; Whitehouse, D. 2001, 85). ${ }^{6}$ Постоје примерци без икаквог рељефног печата. Рељефни печати произвођача, као што је напоменуто, уочени су само на базама две Меркур боце из Народног музеја у Пожаревцу: геометријски мотив у виду кругова постављених у угловима и средишњем делу базе (Кат. 2, Т. 2) и рељефно изведен флорални мотив у виду четворолисне розете (Кат. 3, Т. 3). ${ }^{7}$ Описани рељефни печати произвођача слични су печатима на базама бочица с простора античке Либурније, које су, због мање запремине, односа реципијента и врата $1: 2$, специфичне морфологије, али и квалитета и боје стакла које је тање, означене као псеудо-Меркур бочице и сматрају се производом локалних радионица (Fadić, I. 2011, 336, S1. 3:6, S1. 3:9). Меркур боца са кружним испупчењима на бази нађена је и на некрополи у Будви, у гробној конструкцији XXVI, која је помоћу Трајановог новца (98-117 н. е.) датована у период II века (Marković, Č. 2012, 183, T. 104, 14).

\footnotetext{
${ }^{6}$ Печати на базама Меркур боца предмет су студиозних и вишегодишњих истраживања. Више о рељефним печатима погледати у: Arveiller, V. 2006, 12-132; Buljević, Z. 2011, 180-181; Gandolfi, D. 2002, 295-302; Foy, D. 2009, 144-153; Fadić, I. 2011, 335; Eterović, A., Štefanac, B. 2013, 134.

${ }^{7}$ Рељефни печати су слабо видљиви, што је онемогућило квалитетну фотографију и цртеж.
} 
Производња Меркур боца највероватније је започета крајем I века, трајала је током II и III века, када је произведен највећи број ових посуда, са смањеним капацитетима и у IV веку (Isings, 1957, 100-101). Упркос новијим истраживањима која анализирају рељефне печате на дну, дистрибуцију, квалитет стакла и израде, још увек се не могу прецизно одредити радионице у којима су боце произведене, али се могу претпоставити области у којима су се радионице налазиле, сагледати хронолошки оквири производње у областима и јасније дефинисати путеви које су ове посуде прелазиле до крајњих корисника. Пратећи највећу концентрацију налаза Меркур боца, уједначеност ознака радионица или мајстора, аналогије рељефних представа, може се претпоставити да је постојало неколико производних центара. Највећи број посуда нађен је у северним деловима Галије, на територији данашње Француске, нарочито око Ремса, у долини Роне, око Арла; у Швајцарској; Белгији и у Доњој Германији, у долини Рајне, око Келна. Мањи проценат се може уочити на локалитетима у северном делу Италије, у долини реке По и око Рима; у Словенији и Хрватској. На појединим примерцима који потичу са територије Ломбардије, Хрватске и Словеније уочени су печати радионица или мајстора који се не могу видети на боцама из Галије или Германије. На територији Велике Британије и Иберијском полуострву ове тоалетне боце су веома ретке (Arveiller, V. 2006, 125-132; Calvi, M.C. 1968, 58; Foy, D. 2015. 377-384, Foy, D. 2017, 265-300; Gandolfi, D. 2002, 298; Lazar, I. 2003, 173; Mandruzzato, L. 2007, 134; Morin-Jean, 1913, 66; Stern, M. 1977, 65-66; Whitehouse, D. 2001, 85).

Меркур боце су редак налаз на некрополама на територији Србије. Осим на некрополама Више гробаља и Пећине, потврђене су на некрополи Гомилице на Космају (Глумац, М. 2014, 53, сл. 126) ${ }^{8}$, на некрополи у Коловрату и у Костолу (Pontes) (Ružić, M. 1994, 20). Период у коме су виминацијумске Меркур боце биле у употреби представља период најинтензивније производње ових посуда, нарочито на простору северне и источне Галије, али се само на основу технике израде, квалитета и боје стакла, рељефних печата на дну боца, односно њиховог недостатка, а без релевантних анализа, не може прецизно одредити из којих радионичких центара потичу. Оне свакако представљају вредан налаз који указује на потребу и жељу за луксузнијим производима, као и на трговинску везу са западним и северним провинцијама Царства током II и III века. ${ }^{9}$

\footnotetext{
${ }^{8}$ Меркур боца нађена у гробу типа Мала Копашница Сасе I означеном као Г24 похрањена је у Збирци Дуњић Народног музеја у Београду.

${ }^{9}$ Срдачно захваљујем колегиници Драгани Спасић-Ђурић, музејском саветнику Народног музеја у Пожаревцу на уступљеном материјалу.
} 


\section{Каталог}

\section{1. Боца (Т. 1)}

Локалитет Пећине (1987.), Ц-12709, гроб спаљеног покојника G1-1122

Техника: дување у калуп

$\mathrm{B}=16,8$ цм, Ш дна $=3,0$ цм, Р обода $=4,0$ цм

Инв. бр. ЦР 2570

Боца дебљих зидова, издуженог четвртастог реципијента који се при дну благо сужава, цилиндричног врата. Обод је разгрнут, прстенасто профилисан. Раме је наглашено. Реципијент украшен елипсоидним удубљењима. Дно је благо удубљено. Рађена је од дебљег, слабо прозирног стакла зеленкасте боје.

Однос реципијента и врата је приближно 1:1.

Датовање: прва половина II века

Непубликована.

\section{2. Боца (Т. 2)}

Локалитет Више гробаља (1984.), Ц-1733, гроб спаљеног покојника Г-129 Техника: дување у калуп

$\mathrm{B}=14,4$ цм, Ш = 3,7 цм, Р обода $=3,8$ цм

Инв. бр. ЦР 2483

Фрагментована боца дебљих зидова, издуженог четвртастог реципијента који се при дну благо сужава, цилиндричног врата. Обод је разгрнут, прстенасто профилисан. Раме је наглашено. Дно је благо удубљено, на угловима и у средини распоређени су рељефно изведени кружићи, слабо видљиви. Рађена је од дебљег, слабо прозирног стакла зеленкасте боје.

Однос реципијента и врата је приближно 1:1.

Датовање: II-III век

Публикована: Zotović, 1990, 92.

\section{3. Боца (Т. 3 )}

Локалитет Више гробаља (1984), Ц-5051, гроб спаљеног покојника Г1-625 Техника: дување у калуп $\mathrm{B}=16,6$ цм, Ш = 3,1 цм, Р обода $=3,6$ цм Инв. бр. ЦР 2545

Боца дебљих зидова, издуженог четвртастог реципијента који се при дну благо сужава, цилиндричног врата. Обод је разгрнут, прстенасто профилисан. Раме је наглашено. Дно је благо удубљено са рељефним печатом 
у облику розете са четири латице. Рађена је од дебљег, слабо прозирног стакла зеленкасте боје.

Однос реципијента и врата је приближно 1:1.

Датовање: II-III век

Непубликована.

4. Боца (Т. 4)

Локалитет Више гробаља (1984.), Ц-5052, гроб спаљеног покојника Г1-625

Техника: дување у калуп

$\mathrm{B}=21$ цм, Ш $=4,8$ цм, Р обода $=4,2$ цм

Инв. бр. ЦР 2494

Фрагментована боца дебљих зидова, издуженог четвртастог реципијента цилиндричног врата. Обод је разгрнут, прстенасто профилисан. Раме је наглашено. Дно је благо удубљено. Рађена је од дебљег, слабо прозирног стакла млечнобеле боје.

Однос реципијента и врата је приближно 1:1.

Датовање: II-III век

Непубликована.

\section{5. Боца (Т. 5)}

Локалитет Више гробаља (1984.), Ц-5693, гроб спаљеног покојника Г1-719 Техника: дување у калуп

$\mathrm{B}=16$ цм, Ш = 3 цм, Р обода $=3$ цм

Инв. бр. /

Фрагментована боца дебљих зидова, издуженог четвртастог реципијента и цилиндричног врата. Обод је разгрнут, прстенасто профилисан. Раме је наглашено. Дно је благо удубљено. Рађена је од дебљег, слабо прозирног, беличастог стакла.

Врат је дужи у односу на реципијент.

Датовање: прва половина II века

Непубликована.

\section{БИБЛИОГРАФИЈА}

Arveiller, V. 2006. Les bouteilles Mercure. Corpus des signatures et marques sur verres antiques (Vol. 1). Lyon: 125-132.

Buljević, Z. 2011. Imprints on the bottoms of glass bottles from Dalmatia held in the Archaeological Museum in Split, in: D. Foy, M-D. Nenna, (eds.). Corpus des signatures et marques sur verres antiques 3. Aix-en-Provence - Lyon: 179-195. 
Calvi, M. C. 1968. I vetri romani del Museo di Aquileia. Aquileia: Associazione Nazionale per Aquileia.

Eterović, A. i Štefanac, B. 2013. Mercury Bottles from the Site of Vrt Relja in Zadar, in: Per un corpus dei bolli su vetro in Italia, Atti delle XIV Giornate Nazionali di Studio sul Vetro, Trent. Diani, M. G., Mandruzzato, L. (dir.), 16-17 ottobre 2010, Crémone, 133137. Association international pour l'histoire du verre (coll. AIHV - Atti delle Giornate Nazionali di Studio sul Vetro). Comitato Nazionale Italiano.

Fadić, I. 2005. Merkur boca iz Arheološkog muzeja Istre u Puli. Histria antiqua 13: 205-2011.

Fadić, I. 2011. Pseudo Merkur bočice s područja Liburnije - proizvodi lokalne staklarske radionice. Rimske keramičarske i staklarske radionice. Proizvodnja i trgovina na jadranskom prostoru. Zbornik I međunarodnog arheološkog kolokvija Crikvenica. Ur. G. Lipovac Vrkljan; I. Radić Rossi; B. Šiljeg, Crikvenice, 23-24. oktobar 2008, Crikvenice, Hrvatska, 333-360. Crikvenica: Institut za arheologiju, Grad Crikvenica, Muzej grada Crikvenice.

Foy, D. 2009. La Bouteille Mercure CEVHODIA d'Arles: Cheminements et vicissitudes d'une documentation archéologique. Journal of Glass Studies Vol. 51: 144-153.

Foy, D. 2015. Les marques sur les récipients en verre découverts en Gaule: indices de production et de relations commerciales (milieu du Ier s.-Ve s. apr. J.-C.). Gallia 72/2: 351-401.

Foy, D. 2017. An Overview of the Circulation of Glass in Antiquity, in: Trade, Commerce and the State in the Roman World. Ed. A. Wilson, A. Bowmann, actes du colloque du 1-3 October 2009, Oxford, 265-300, Oxford: Oxford University Press.

Gandolfi, D. 2002. Una bottiglia-mercuriale Isings 84 con bollo C. EVHODIA dal Civico Museo Archeologico di Ventimiglia (Liguria, Italia), in: Vivre, produire et échanger : reflets méditerranéens. Miscellanes offerts a Bernard Liou Istres, 295-302. ed. Montagnac: Monique Mergoil.

Глумац, М. 2014. Римска некропола Губереваи - Гомилице на Космају. Соичјална структура становништа од I до III н. е. Докторска дисертација, Универзитет у Београду.

Isings, C. 1957. Roman Glass from dated Finds. Archaeologica Traiectina II. GroningenDjakarta: J. B. Walters.

Lazar, I. 2003. Rimsko steklo Slovenije. Ljubljana: Inštitut za arheologijo ZRC SAZU

Mandruzzato, L. 2007. Nuovi studi e nuove perspettive per lo studio del vetro antico nell'Italia Settentrionale e rapport con l'area Transalpina. Quaderni Friulani di Archeologia XVII: 133-141.

Marković, Č. 2012. Antička Budva; nekropole: istraživanja 1980-1981. Podgorica

Morin-Jean, A. J. 1913. La verrerie en Gaule sous l'Empire romain; essai de morphologie et de chronologie. Paris: H. Laurens.

Ružić, M. 1994. Rimsko staklo u Srbiji. Beograd: Centar za arheološka istraživanja. Knjiga 13.

Спасић-Ђурић, Д. 2002. Виминацијум - Главни град провинщије Горюе Мезије. Пожаревац: Народни музеј у Пожаревцу. 
Stern, E. M. 1977. Ancient Glass at the Fondation Custodia (Collection Frits Lugt) Paris. Archaeologica Traiectina, XII. Groningen: Wolters-Noordhoff.

Taborelli, L. 1983. Nuovi esemplari di bolli già noti su contenitori vitrei dell'area centro-italica (Regg. IV, V, VI). Picus, studi e ricershe sulle Marche nell'antichita 3: 23-69. Vojvoda, M. i Mrđić, N. 2015. Nalazi novca sa viminacijumske nekropole Više grobalja i njihova uloga u pogrebnom ritualu. Beograd: Arheološki institut.

Vojvoda, M. i Mrđić, N. 2017. Nalazi novca sa viminacijumske nekropole Pećine i njihova uloga u pogrebnom ritualu. Beograd: Arheološki institut.

Von Saldern, A. 2004. Antikes Glas. Handbuch der Archäologie. München: C. H. Beck. Whitehouse, D. 2001. Roman Glass in the Corning Museum of Glass. Vol.2. Corning Museum of Glass. New York: Hudson Hill Press.

Zotović, Lj. i Jordović, Č. 1992. Viminacium: nekropola Više grobalja. Beograd: Arheološki institut, Republički zavod za zaštitu spomenika kulture. 


\title{
Antonija S. Ropkić Đorđević
}

Beograd

\section{MERCURY BOTTLES FROM THE NATIONAL MUSEUM IN POŽAREVAC}

\author{
Keywords: National Museum in Požarevac, Viminacium, \\ necropolis, glass vessels, Mercury bottles
}

This paper presents very interesting and not particularly common glass vessels named after the image of the god Mercury which was on the bases of some of these bottles. Beside the god Mercury, some bases have various relief decorations: the name or mark of the manufacturer, animals, floral or geometric decorations: palm, rosettes, amphora, dots in the corners, crosses, Fortuna or a genius with a cornucopia. There are also examples with no relief stamps.

Mercury bottles can be dated into the period from the end of the $1^{\text {st }}$ century to the early $4^{\text {th }}$ century $\mathrm{AD}$, but the majority of these vessels are dated into the $2^{\text {nd }}$ and $3^{\text {rd }}$ century. Different variations of the base relief stamps indicate that they were produced in different production centres of the western part of the Roman Empire, particularly in the Rhine region, and especially around Cologne, Rhone Valley water routes and Northern Italic region, primarily grouped in Rome and along the Po Valley water routes. Distribution of the vessels indicates the movement of products between provinces and developed trade with the Balkans and eastern provinces.

There are five Mercury bottles in the collection of the National Museum in Požarevac, found during rescue excavations of the Viminacium necropoles Više Grobalja and Pećine. Mercury bottles were found in cremation burials from the $2^{\text {nd }}$ and $3^{\text {rd }}$ century AD. These medium size bottles have a four-sided body and a long cylindrical neck, with a horizontal and flattened rim. The long neck and narrow mouth prevented rapid evaporation of the contents, probably medicinal or aromatic substances. Bottles from the National Museum in Požarevac were made of greenish and whitish opaque glass or glass of limited transparency, with thick walls. They were blown into a mould, with a loosely formed neck and rim. Two bottles have a relief stamp on the base: four-leaf rosettes and four embossed circles in the corners and embossed circles in the centre. Their closest analogies are pseudo-Mercury bottles, products of a local glass workshop or workshops from the eastern Adriatic coast, former southern Liburnia, and a Mercury bottle with four circles in the corners and the centre of the base, from a necropolis in Budva. 
Mercury bottles from the National Museum in Požarevac collection can be dated into the period from the first half of the $2^{\text {nd }}$ to the mid- $3^{\text {rd }}$ century $A D$ and their dating is confirmed by some of the grave goods. Based on their glass colour and quality, production technique and relief stamps or lack of the stamps on the bases, it is not possible to determine their workshop provenance, but they are certainly good examples of demand for luxury products and interactions with the western provinces of the Roman Empire. 

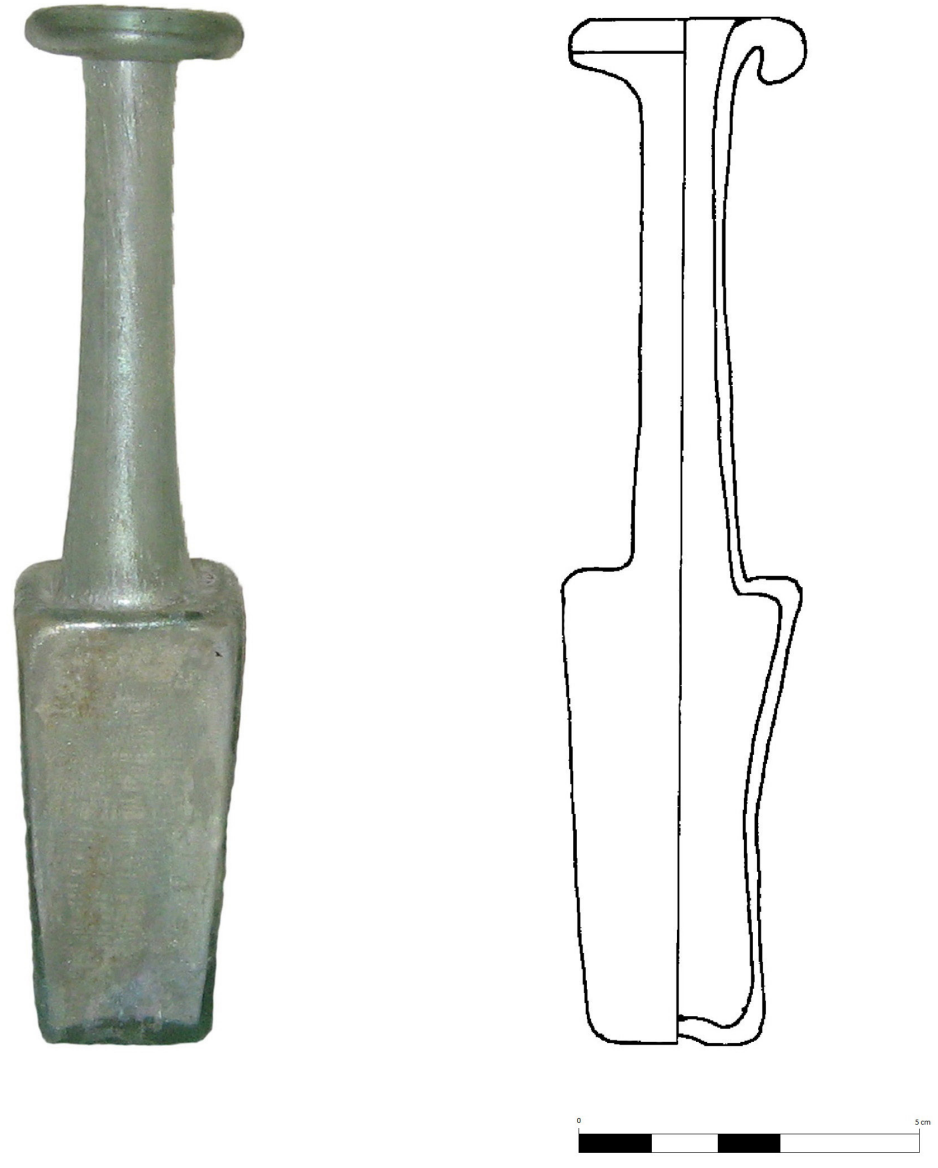

T. I Меркур боца Ц-12709, локалитет Пећине, Г1-1122

PI. I Mercury bottle C-12709, the necropolis of Pećine, grave G1-1122 

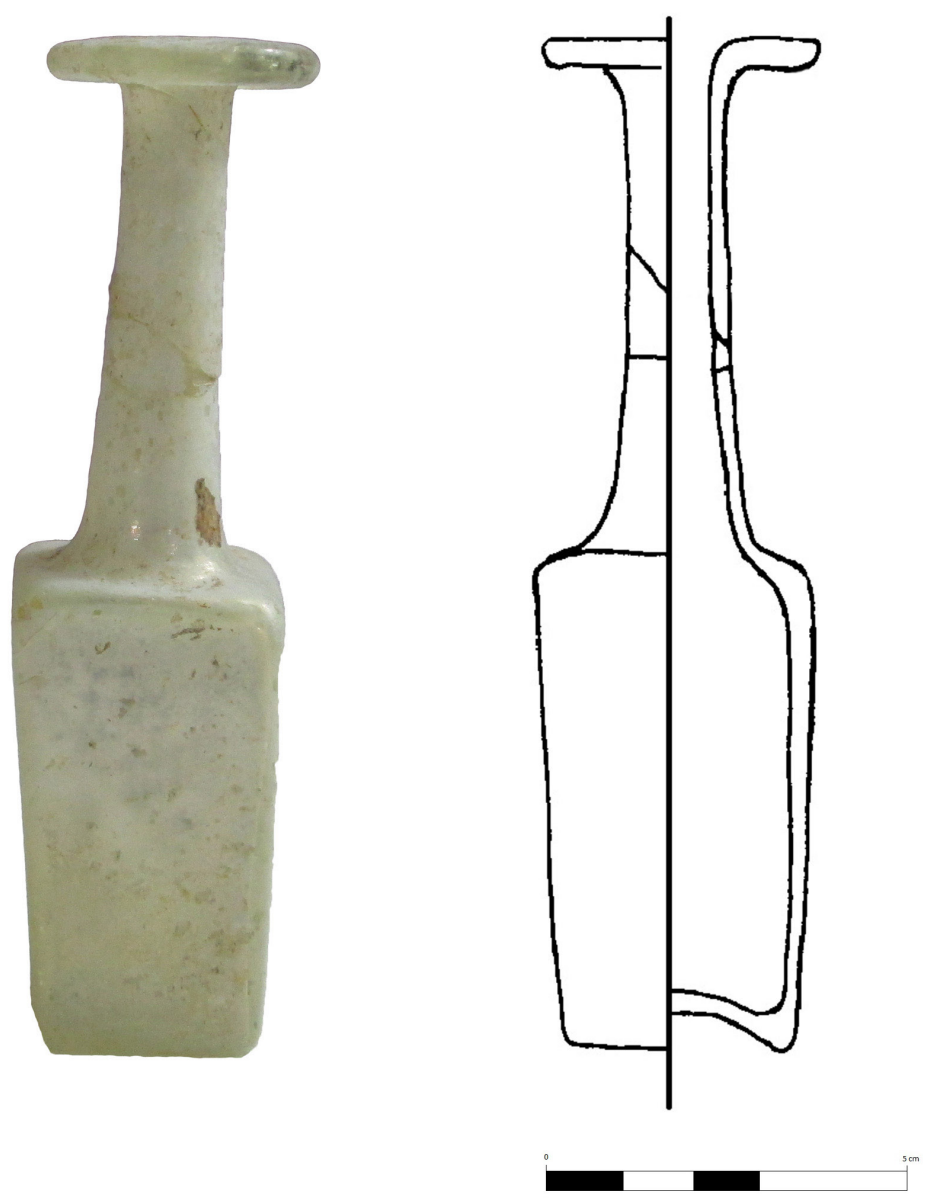

T. II Меркур боца Ц-1733, локалитет Више гробаља, Г1-129

PI. II Mercury bottle C-1733, the necropolis of Više Grobalja, grave G1-129 

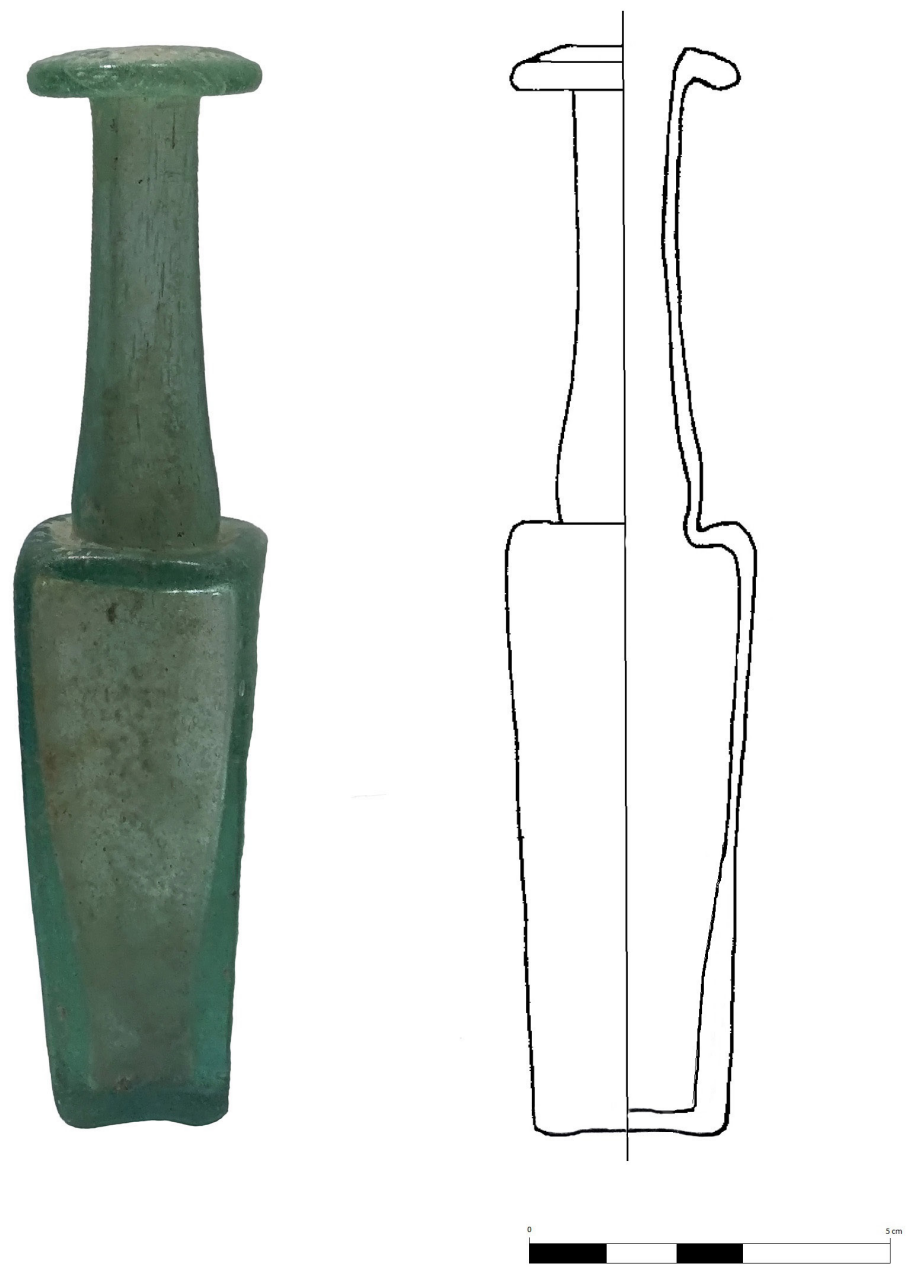

T. III Меркур боца Ц-5051, локалитет Више гробаља, Г1-625

PI. III Mercury bottle C-5051, the necropolis of Više Grobalja, grave G1-625 



T. IV Меркур боца Ц-5052, локалитет Више гробаља, Г1-625

PI. IV Mercury bottle C-5051, the necropolis of Više Grobalja, grave G1-625 

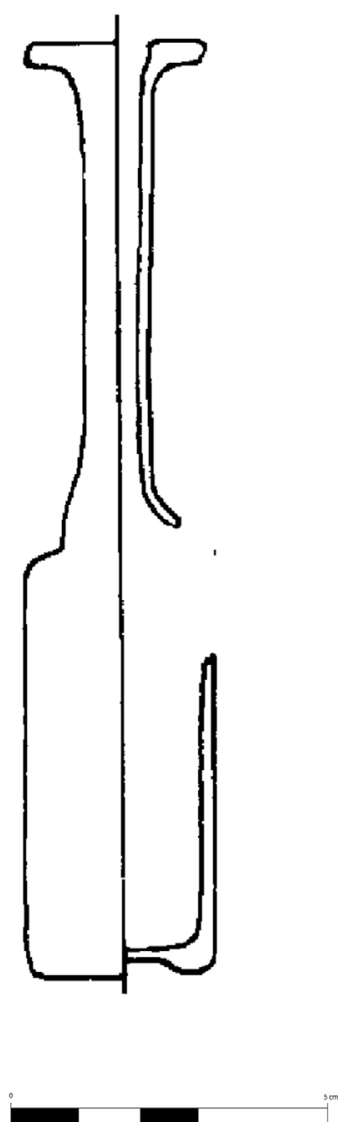

T. V Меркур боца Ц-5693, локалитет Више гробаља, Г1-719

PI. V Mercury bottle C-5693, the necropolis of Više Grobalja, grave G1-719 